logos_i_ethos_2021_2_(58), s. 127-145

https://doi.org/10.15633/lie.4173

Karol Petryszak

https://orcid.org/0000-0001-9058-4721

Uniwersytet Papieski Jana Pawła II w Krakowie

\title{
Miejsce czy miejsca? Kilka uwag na temat propozycji Romana Ingardena dotyczących łączenia intencjonalnych i rzeczywistych miejsc w dziele literackim
}

Gdy pod koniec lat 20. XX wieku Roman Ingarden przystąpił do badania dzieła literackiego ${ }^{1}$, była to tematyka jeszcze stosunkowo słabo opracowana, zwłaszcza w kontekście filozoficznych badań nad tekstem literackim ${ }^{2}$. Mimo tego Ingarden przedstawił w zasadzie dość całościową - a w następnych latach szeroko uzupełnianą - koncepcję dzieła literackiego. Oczywiste jest, o czym sam autor wielokrotnie
Karol Petryszak - asystent w Katedrze Filozofii Kultury Wydziału Filozoficznego UPJPII w Krakowie. W prowadzonych badaniach zajmuje się filozofią literatury, filozofią kultury, ontologią oraz współczesnymi ideologiami. Zwraca szczególną uwagę na precyzyjne stosowanie terminologii fachowej oraz założenia kryjące się za poszczególnymi koncepcjami. Autor m.in.: Ontologia kultury. Badania nad kultura $w$ oparciu o zmodyfikowana ontologie Romana Ingardena (2021), Ogród Eden na wschodzie, czyli materializm dialektyczny $w$,Drugiej płci” autorstwa Simone de Beauvoir (2019). wspominał, że dzieło literackie było jedynie dogodnym przedmiotem badania, służącym do opracowania ontologicznej problematyki bytów intencjonalnych (ew. czysto intencjonalnych) lub - gdyż jeszcze w momencie opracowywania $O$ dziele literackim nie była przesądzona sprawa

1 Dokładnie chodzi o zimę 1927/28. Zob. R. Ingarden, O dziele literackim. Badania z pogranicza ontologii, teorii języka i filozofii literatury, Warszawa 1960, s. 9.

2 Por. M. Głowiński, O konkretyzacji, w: M. Głowiński, Style odbioru: szkice o komunikacji literackiej, Kraków 1977, s. 91-92. 
bytów intencjonalnych - po prostu czegoś, co istnieje (ew. może istnieć), ale inaczej niż na sposób realny lub idealny ${ }^{3}$. Poza szczegółową eksplikacją warstwowej budowy dzieła literackiego Ingarden w paragrafie 25. dyskutuje kwestię quasi-sądów przysługujących zdaniom orzekającym w dziele literackim, które to quasi-sądy przynależą do tzw. warstwy tworów znaczeniowych ${ }^{4}$ W ramach tych rozważań autor Sporu o istnienie świata wygłasza kilka uwag na temat łączenia intencjonalnych i rzeczywistych stanów rzeczy (ew. przedmiotów) w ramach dzieła literackiego. Przyjmowana przez niego perspektywa wykracza poza oczywisty kontekst samej budowy dzieła literackiego i kieruje się ku kwestiom omawianym w $O$ poznawaniu dzieła literackiego ${ }^{5}$. Niemniej, abstrahując od pewnych antycypacji zawartych w paragrafie 25., w niniejszym artykule chcę się skupić na pokazaniu pewnego alternatywnego rozwiązania poruszonej przez krakowskiego filozofa kwestii, które to rozwiązanie ostatecznie może zostać - pod pewnymi warunkami - włączone w całościową koncepcję dzieła literackiego Ingardena jako jedna z możliwych wariacji. Centralna teza, którą będę starał się przedstawić i obronić, brzmi: między jakimkolwiek elementem świata przedstawionego a jakimkolwiek elementem świata rzeczywistego nie może zachodzić pełna takożsamość ${ }^{6}$, tożsamość ${ }^{7}$ ani identyczność ${ }^{8}$. Teza ta dotyczy

3 Zob. R. Ingarden, O dziele literackim, s. 8.

4 Zob. R. Ingarden, O dziele literackim, s. 229-244.

Szerzej na temat trudności związanych z kwestiami quasi-sądów zob. np. J. Pelc, Quasi-sądy a dzieło literackie, w: „Pamiętnik Literacki” 54 (1963) 3, s. 61-79. Nie dyskutuję tu zasadności koncepcji Ingardena związanej z quasi-sądami. Przyjmuję je jako aksjomat. Natomiast warto odnotować, że nie jest to stanowisko w pełni przyjmowane i pozbawione miejsc i konsekwencji budzących wątpliwości.

5 Zob. R. Ingarden, O poznawaniu dzieła literackiego, Warszawa 1976, zwł. \$11.

${ }^{6}$ Gdzie przez pełną takożsamość rozumiem: podobieństwo między dwoma różnymi od siebie elementami (obojętnie czy będą to przedmioty, stany rzeczy czy miejsca itd.), które nie dopuszcza między nimi jakiejkolwiek różnicy przy jednoczesnym zachowaniu ich wzajemnej odrębności.

7 Gdzie przez tożsamość $\mathrm{w}$ tym kontekście rozumiem: istnienie w danym wypadku jednego bytu, który z różnych przyczyn jest przedstawiany czy rozpoznawany jako dwa byty (np. do pewnego momentu w historii Gwiazda Wieczora i Gwiazda Zaranna).

${ }^{8}$ Gdzie przez identyczność rozumiem to samo, co przez pełną takożsamość, ale wymieniam również identyczność ze względu na podkreślenie - gdyby z jakichś względów należało zrezygnować z pełnej takożsamości na rzecz jedynie takożsamości (czyli podobieństwa między dwoma różnymi 
w kontekście propozycji Ingardena dokładnie miejsca rozgrywania się akcji i zachodzenia pewnych stanów rzeczy.

Dalsze rozważania zostały podzielone na trzy części. Najpierw zostanie przedstawione stanowisko Ingardena w omawianej kwestii (przede wszystkim na podstawie uwag zamieszczonych na kilku stronach z paragrafu 25. ${ }^{9}$ ) wraz ze wskazaniem wybranych trudności, które mogą z niego płynąć. Następnie zaprezentuję alternatywne rozwiązanie i trudności, jakich może ono nastręczać. W ramach zakończenia wskażę, dlaczego proponowane rozwiązanie da się wpisać w szerszą koncepcję dzieła literackiego opracowaną przez Ingardena.

\section{Stanowisko Ingardena}

Autor Sporu o istnienie świata wiele pism poświęcił kwestii sądów ${ }^{10}$. Pominąwszy dyskusje, które czy to otwarcie, czy tylko kontekstowo i „między wierszami” prowadził ze zwolennikami ówcześnie popularnej logiki pozytywistycznej i psychologistycznej, sam zaproponował wiele istotnych rozwiązań, które kwestie sądów stawiały niemalże w centrum jego rozważań, zwłaszcza w kontekście epistemologiczno-informacyjnym. Tym bardziej ugruntowane są wobec tego jego rozważania na temat quasi-sądów. Omawiając związane z nimi zagadnienia, polski fenomenolog pisze:

Najbliżej czystych zdań orzekających stoją zdania twierdzące o charakterze quasi-sądów w dziełach literackich, które w żadnym sensie nie są dziełami „historycznymi” (...). Dochodzi tu niewątpliwie do „osadzenia” w bycie intencjonalnie wytworzonych stanów rzeczy (resp. przedmiotu w nich przedstawionego), które naturalnie są również odpowiednio egzystencjalnie scharakteryzowane. Brak tu jednak całko-

od siebie elementami, które nie musi dotyczyć wszystkich cech itd.) - że owa pełna takożsamość (ew. identyczność) jest tu kwestią zasadniczą i nie można z niej rezygnować w rozważaniach nawet wówczas, jeżeli z jakiegoś względu będzie trzeba przejść od pełnej takożsamości do jedynie takożsamości.

9 Chodzi dokładnie o strony 232-243 wydania z roku 1960.

10 Zob. w zasadzie większą część tomu: R. Ingarden, Z teorii języka i filozoficznych podstaw logiki, Warszawa 1972. 
wicie - charakterystycznego dla zdań, które naprawdę są sądami, przeświadczenia o dokładnym dostosowaniu wytworzonego intencjonalnie stanu rzeczy do odpowiedniego obiektywnie zachodzącego i zastanego w pewnej bytowo samoistnej dziedzinie ${ }^{11}$.

W dalszej kolejności Ingarden dodaje, że stany rzeczy, które zostają wytworzone intencjonalnie, są dość ściśle odseparowane od świata (ew. dziedziny bytowej) świata realnego. Można powiedzieć, że tworzą własny świat ${ }^{12}$. Niemniej, zgodnie z koncepcją przeniesienia, przedmioty świata intencjonalnego są niejako właśnie przenoszone na grunt świata rzeczywistego. Nie znaczy to oczywiście, że występują lub występowały $\mathrm{w}$ realnej (ew. idealnej) rzeczywistości jako realne (ew. idealne). One jedynie imitują - ze względu na podobieństwo czy też identyczność formalno-materialną (ew. formalno-treściową) - przedmioty i stany rzeczy realnie lub idealnie istniejące. Dokonuje się to m.in. dzięki wskaźnikowi kierunkowemu znaczeń nazwowych ${ }^{13}$. Innymi słowy, jeśli jakiś stan rzeczy zachodzi w jakimś miejscu, które jest nazwowo oddane jako np. „kamienica przy ul. Bernardyńskiej” czy „park obok stadionu Wisły”, to owo wyrażenie nazwowe odnosi czytelnika nie do jakiegoś wymyślonego miejsca, ale do jakiegoś konkretnego, realnego miejsca. Ingarden oczywiście zaznacza, że mniej lub bardziej zdajemy sobie sprawę jako

11 R. Ingarden, O dziele literackim, s. 237-238.

12 R. Ingarden, O dziele literackim, s. 239.

Można w tym miejscu podnieść pewną wątpliwość dotyczącą tego, jak należy rozumieć ów odrębny świat intencjonalnych stanów rzeczy. Zaznaczam tu trzy możliwe rozumienia (przy czym Ingarden najprawdopodobniej opowiedziałby się za rozumieniem pierwszym, co zakładam na potrzeby dalszej części rozważań): 1. każde dzieło literackie jako zamknięta ustrukturyzowana i skończona całość znaczeniowa stanowi własny świat intencjonalnych stanów rzeczy, tj. świat znany z jednej z powieści Elizy Orzeszkowej byłby odrębny od świata znanego z sagi o wiedźminie autorstwa Sapkowskiego; 2. wszystkie intencjonalne stany rzeczy stworzą jedno uniwersum (ew. świat); 3. wszystkie znane danemu podmiotowi intencjonalne stany rzeczy stanowią jeden świat dany właśnie temu podmiotowi - z czego wynika, że tyle byłoby światów, ile byłoby podmiotów poznających. Są to jedynie wskazania możliwych rozwiązań przedstawione ze względu na pewne niedoprecyzowanie występujące w koncepcji Ingardena. Jak jednak zostało wskazane, z kontekstu jego pracy wynika, że opowiedziałby się raczej za rozwiązaniem pierwszym.

13 Szerzej na temat wskaźników kierunkowych zob. R. Ingarden, O dziele literackim, s. 100-105. 
odbiorcy dzieł literackich z intencjonalności świata przedstawionego, jednak wskazuje też, że w nastawieniu naturalnym - o ile można w tym kontekście tak powiedzieć - właśnie ze względu na splatanie się czynników formalno-materialnych (ew. formalno-treściowych) w nazwie (lub nawet $w$ większych jednostkach znaczeniowych) następuje niejako utożsamienie przedmiotu czy stanu rzeczy intencjonalnego i realnego (ew. idealnego $)^{14}$. Ingarden owo przenoszenie elementów ściśle intencjonalnie wytworzonych na grunt czy na tło świata rzeczywistego przyrównuje do zjawiska opalizowania, które rozumie jako niejednoznaczny stan pewnego - z epistemologicznego punktu widzenia - „«bycia przeniesionym w świat [rzeczywisty]», a zarazem «pozostawania jedynie gdzieś w zawieszeniu» i niemożność stanięcia gdzieś w określonym miejscu na stałym gruncie"15.

Innym przykładem imitowania rzeczywistości jest takie budowanie intencjonalnych stanów rzeczy (ew. przedmiotów), których funkcją nie jest odpowiadanie jakimś konkretnym elementom przeszłej rzeczywistości, lecz imitowanie możliwego ich istnienia w danej epoce czy w danym kontekście ${ }^{16}$. Nie więc jakiś konkretny element rzeczywistości jest tu pierwowzorem - lub idea, której konkretyzacja w świecie rzeczywistym i w świecie intencjonalnym wypływałyby z jednego źródła ${ }^{17}$ - ale sam klimat odmalowujący tło danej epoki, społeczeństwa itd. dopuszcza ów wykreowany element jako możliwy i pasujący ${ }^{18}$. Owo dopasowanie

14 Zob. R. Ingarden, O dziele literackim, s. 235.

15 R. Ingarden, O dziele literackim, s. 239.

Należy wskazać, że nie mówię to u przestrzeni przedstawionej, której według Ingardena kategorycznie nie należy łączyć z przestrzenią rzeczywistą: „Przestrzeń przedstawiona nie da się także włączyć ani w realną przestrzeń, ani w różne spostrzeżeniowe przestrzenie zorientowane, uporządkować jako ich część czy kawałek i na nawet wtedy, gdy przedmioty przedstawione są wyraźnie przedstawione jako «znajdujące się» w określonej okolicy realnej przestrzeni (np. «w Monachium» czy «w Krakowie»). Owo przedstawione «Monachium», a zwłaszcza przestrzeń, w której to miasto «leży», nie da się jako przedstawiona utożsamić z odnośnym wycinkiem realnej przestrzeni, w którym realne miasto Monachium rzeczywiście się znajduje" (R. Ingarden, O dziele literackim, s. 289).

16 Dodatkowo por. M. Głowiński, O konkretyzacji, dz. cyt.

17 Zob. R. Ingarden, O dziele literackim, s. 232.

18 Zob. R. Ingarden, O dziele literackim, s. 239-240. 
przedmiotu (ew. stanu rzeczy) do tła dokonuje się ze względu na podobieństwo czy może wręcz - w niektórych przypadkach - identyczność formalno-materialną (ew. formalno-treściową) tła świata przedstawionego i np. jakiejś epoki historycznej. Ingarden oczywiście widzi zasadnicze różnice między odmalowanym literacko opisem bitwy np. pod Waterloo a zapiskami historycznymi opisującymi tę bitwę, ale znów m.in. dzięki wskaźnikowi kierunkowemu znaczeń nazwowych, jak też bardziej złożonych jednostek znaczeniowych oraz kwestiom formalno-materialnym (ew. formalno-treściowym) owo podobieństwo zostaje przez odbiorcę niejako ukonstytuowane. Polski filozof podkreśla tę kwestię następującą uwagą: „Dzięki odpowiedniemu dostosowaniu do ogólnego typu przedmiotów realnych danej epoki zostają czysto intencjonalne stany rzeczy przecież przeniesione do rzeczywistości”19. Czy podobieństwo to występuje faktycznie, to inna sprawa, którą będę rozważał w kolejnej części artykułu.

Biorąc za przykład powieść historyczną, której celem jest jak najwierniejsze odmalowanie tła epoki, ale także pewnych faktycznie zaszłych wydarzeń, Ingarden wskazuje, że może w jej ramach dojść do identyfikowania przedstawionych, a więc intencjonalnych stanów rzeczy czy nawet konkretnych intencjonalnych indywidualnych przedmiotów ze stanami rzeczy czy indywiduami, do których te się odwołują (ew. które imitują) ${ }^{20}$. Polski fenomenolog zwraca uwagę, że tu również zachodzi myślowe przeniesienie sprojektowanych myślowo przedmiotów czy stanów rzeczy $\mathrm{w}$ świat realny $\mathrm{y}^{21}$.

Aby dobrze wybrzmiał przedstawiany wycinek koncepcji Ingardena, należy podkreślić, że dzieło literackie według autora Sporu o istnienie świata nie może zawierać faktycznych sądów ${ }^{22}$. Gdyby takie sądy

19 R. Ingarden, O dziele literackim, s. 240.

20 Zob. R. Ingarden, O dziele literackim, s. 241-242.

21 Zob. R. Ingarden, O dziele literackim, s. 242.

${ }^{22}$ Kwestia ta była już dyskutowana w literaturze. Zob. np. J. Pelc, Quasi-sądy a dzieło literackie, dz. cyt.; J. Ziomek, Fikcyjne pole odniesienia a problem quasi-sq̨dów, w: Wypowiedź literacka a wypowiedź filozoficzna, pod red. M Głowińskiego i J. Sławskiego, Wrocław-Warszawa 1992, s. 199nn. Należy jednak podkreślić, że propozycja Ingardena, chociaż współcześnie zarzucona w zasadzie 
zawierało, to nie można byłoby mówić o jakimkolwiek „odtwarzaniu”, „udawaniu”, „imitowaniu” czy „naśladowaniu”. W takim przypadku to, co Ingarden określa mianem wskaźnika kierunkowego, musiałoby - posługując się wyrażeniem polskiego fenomenologa - „trafiać przedmioty, które ongi rzeczywiście istniały" ${ }^{33}$. W takiej sytuacji ewidentnie nie występowałyby sprojektowane przedmioty intencjonalne czy stany rzeczy. Innymi słowy oznaczałoby to identyczność obu stanów rzeczy pod każdym względem, a nie tylko pod względem formalno-materialnym (ew. formalno-treściowym).

Przedstawione powyżej wskazania są oczywiście jedynie drobnym wyimkiem z rozległej i dość skomplikowanej ontologii dzieła literackiego Ingardena. Jednak właśnie względem jedynie tego wąskiego tematu chciałbym zaproponować pewne alternatywne rozwiązanie. Precyzując, chodzi dokładnie o tytułową łączność intencjonalnych i rzeczywistych stanów rzeczy (ew. przedmiotów). Ingarden wskazał, że ze względu m.in. na nazwowy wskaźnik kierunkowy, jak też podobieństwo (ew. identyczność formalno-materialną) pewne określone, znane $\mathrm{z}$ rzeczywistości miejsca stanowią niejako tło dla tego, co w dziele literackim fikcyjne ${ }^{24}$. Jednocześnie polski fenomenolog wskazuje, że intencjonalne stany rzeczy wchodzące w skład dzieła literackiego, tworzą własny odrębny świat.

niemal zupełnie w studiach nad literaturą, zgadza się z jednym z wyznaczników zaliczenia danego elementu wchodzącego w szerszy zbiór piśmiennictwa do zbioru literatury pięknej. Chodzi tu mianowicie o wielokrotnie podkreślaną w definicjach i opracowaniach niemożność występowania w obrębie literatury pięknej funkcji poznawczej - która np. dominuje w tekstach naukowych (zob. np. Słownik terminów literackich, pod red. M. Głowińskiego i in., Wrocław 2008, s. 283-285). Jeśli zatem możliwość występowania funkcji poznawczej w danym tekście byłaby zależna od występowania w nim sądów, tj. takich sformułowań, którym można przypisać wartość prawdy lub fałszu - przyjmując korespondencyjną definicję prawdy - to teksty, w których nie ma możliwości występowania funkcji poznawczej, musiałyby odznaczać się brakiem sądów. Ingarden wskazuje, że faktycznie tak jest w obrębie dzieła literackiego, gdzie występują zdania, które jedynie przypominają sądy; zdania te określił mianem quasi-sądów.

${ }^{23}$ R. Ingarden, O dziele literackim, s. 242.

${ }^{24} \mathrm{Na}$ ten temat zob. W. Stróżewski, Wokół piękna, Kraków 2002, s. 273nn; D. Ulicka, Ingardenowska filozofia literatury. Konteksty, Warszawa 1992, s. 206nn; A. Szczepańska, Estetyka Romana Ingardena, Warszawa 1989, s. 154nn; M. Głowiński, O konkretyzacji, s. 107. 
Na ile odrębny, to inna kwestia ${ }^{25}$. Połączenie zatem obu „światów” przez przedstawianie faktycznych miejsc rozgrywania się akcji stanowi pewne wyzwanie, z którym Ingarden poradził sobie w przedstawiony powyżej sposób. Wydaje się jednak, że nieco rozszerzając problematykę odpowiedniości obu światów i występujących w nich miejsc, można dojść do nieco innego rozwiązania niż to zaproponowane przez autora Sporu o istnienie świata.

Należy jeszcze wskazać na trudności wynikające $\mathrm{z}$ propozycji Ingardena:

1. Jeśli przyjąć, że są to miejsca te same, takie same lub identyczne, konieczne jest zachodzenie możliwości wykazania ich takożsamości, tożsamości czy identyczności nie tylko pod względem formalno-materialnym (ew. formalno-treściowym) i pod względem kierunkowego wskaźnika nazwy, ale też pod względem relacji wewnętrznych i zewnętrznych konstytuujących dane miejsce. Trudno powiedzieć, jakie rozwiązanie polski myśliciel przedstawiłby w odpowiedzi, gdyż nie zajął się tą tematyką dostatecznie, aby móc o tym na podstawie jego prac wyrokować. Dalej będę starał się pokazać, że takie utożsamienie nie jest jednak w pełni możliwe.

2. Ingarden wskazywał, że zarówno elementy świata realnego, jak i elementy świata przedstawionego można traktować jako pewnego rodzaju konkretyzacje idei i jakości idealnych ${ }^{26}$. Cała trudność polega w tej argumentacji na przyjęciu istnienia idei i jakości idealnych. Nie miejsce tu na dyskusję z tą propozycją polskiego filozofa. Należy jednak mieć na uwadze, że część rozstrzygnięć w ramach ontologii literatury wynika

25 Nie chodzi tu rzecz jasna o tak ścisłą separację, jak między dziedziną bytów realnych i idealnych, którą w innych miejscach postulował Ingarden. Zob. R. Ingarden, O pytaniach esencjalnych, w: R. Ingarden, Z teorii języka i filozoficznych podstaw logiki, s. 364; E. Świderski, Pewne główne rysy ontologii Ingardena, „Studia Philosophiae Christianae” 14 (1978) nr 1, s. 89; M. Rosiak, Spór o substancjalizm. Studia z ontologii Ingardena i metafizyki Whiteheada, Łódź 2003, s. 204-205; A.B. Stępień, Uwagi o Ingardenowskiej koncepcji ontologii, w: Spór o Ingardena, pod red. J. Dębowskiego, Lublin 1994, s. 20-21.

${ }^{26}$ Dlaczego „pewnego rodzaju”? Szerzej na ten temat zob. M. Rosiak, Zagadnienie postaktualności. Z ontologii egzystencjalnej tego, co przeminęło, „Lectiones \& Acroases Philosophicae” 5 (2012) 2, s. 44. 
właśnie z przyjęcia istnienia przez niego osobnej dziedziny bytowej bytów idealnych ${ }^{27}$.

3. Jeśli warunkiem istnienia dzieła literackiego jest niewystępowanie w nim sądów, lecz jedynie występowanie quasi-sądów, to czy na podstawie quasi-sądu możliwe byłoby utożsamienie przez sam wskaźnik kierunkowy nazwy i warstwę formalno-materialną (ew. formalno-treściową) miejsca ze świata przedstawionego z miejscem ze świata rzeczywistego?

4. O ile z kwestią wskaźnika kierunkowego nazwy raczej nie byłoby problemu, to wskazywanie na podobieństwo materialno-formalne (ew. materialno-treściowe) nie jest, jak się wydaje, dostatecznie u Ingardena ugruntowane. Czy nie jest tak, że to właśnie przez podobieństwo nazwy zostaje wytworzone podobieństwo formalno-materialne (ew. formalno-treściowe)? Sprawą tą nie będę się tu zajmował, ale wydaje się, że warto byłoby poświęcić jej osobne rozważania.

\section{Stanowisko alternatywne}

W słynnym eksperymencie z tzw. ziemią bliźniaczą Hilary Putnam wyznaczył pewien alternatywny sposób pomyślenia problemu, przed którym stanął Ingarden ${ }^{28}$. Putnam oczywiście nie odnosił swoich rozważań do świata przedstawionego, ale w dalszej części artykułu będę starał się ekstrapolować i dostosować uzyskane przez niego propozycje do problemu, z którym zmierzył się Ingarden. Aby dobrze zarysować kontekst ekstrapolacji, przywołam akapit wprowadzający w eksperyment:

W poniższych rozważaniach przyjmujemy pojęcie „możliwego świata” jako pojęcie pierwotne. Usprawiedliwia nas poczucie, że owo pojęcie z różnych względów ma sens i jest naukowo istotne, nawet jeśli wymaga uściślenia. Założymy następnie,

27 Szerszą dyskusję na ten temat przedstawiłem w: K. Petryszak, Ontologia kultury. Badania nad kulturą w oparciu o zmodyfikowaną ontologię Romana Ingardena, Kraków 2021, $₫ 4,8$.

${ }_{28}$ Zob. H. Putnam, Znaczenie wyrazu „znaczenie”, w: H. Putnam, „Wiele twarzy realizmu” i inne eseje, Warszawa 1998, s. 117nn. 
że przynajmniej w niektórych przypadkach można mówić o tym samym indywiduum, iż istnieje w więcej niż jednym możliwym świecie ${ }^{29}$.

Aby uzyskać ugruntowanie ekstrapolacji, należy dokonać następujących zmian we wstępnych warunkach eksperymentu. Przede wszystkim to, co Putnam określa jako „świat możliwy” dla prowadzonych tu rozważań zostaje zamienione na świat intencjonalnie sprojektowany, czyli świat przedstawiony w dziele literackim. Sama kwestia istnienia takiego świata może być dyskusyjna, ale pozostając na gruncie ontologii dzieła literackiego, przyjmuję za autorem $O$ dziele literackim, że zachodzi przynajmniej możliwość istnienia takiego świata. Dalej, kwestię tego samego indywiduum istniejącego w więcej niż jednym możliwym świecie można w rozważanej tu sprawie zastąpić występowaniem jednego miejsca w więcej niż jednym świecie (świat przedstawiony i rzeczywisty). Taka ekstrapolacja pozwoli - jak sądzę - na pełne przedstawienie i obronienie centralnej tezy artykułu, że między jakimkolwiek elementem świata przedstawionego a jakimkolwiek elementem świata rzeczywistego nie może zachodzić pełna takożsamość, tożsamość ani identyczność. Zanim przejdę do prezentacji argumentów, przedstawię zasadniczą część Putnamowskiego eksperymentu myślowego.

Putnam przyjął, że istnieją dwa światy co do zasady identyczne ${ }^{30}$. Czyli zarówno w pierwszym, jak i w drugim jest właśnie jakiś konkretny podmiot czytający właśnie w tej chwili te słowa. Wszystko w obu światach dzieje się dokładnie tak samo, obojętnie z jakim poziomem precyzji chcielibyśmy ustalić owo dzianie się ${ }^{31}$. Jedyny wyjątek od tej identyczności stanowi pewna substancja, która, mimo iż ma dokładnie te same właściwości w obu światach, to w jednym świecie jest to związek

29 H. Putnam, Znaczenie wyrazu „znaczenie”, s. 117.

30 W pierwszej części eksperymentu, do której się tu ograniczę, nie chodzi o dwie identyczne planety z identycznymi ludźmi, ale o dwa odseparowane światy. Na ile odseparowane, to z pism Putnama nie wynika.

${ }^{31}$ Odnoszę się tu do argumentacji Karla Poppera, która może mieć w tej kwestii zastosowanie pomocnicze. Por. K. Popper, Wszechświat otwarty. Argumenty na rzecz indeterminizmu, Kraków 1996, s. 31nn. 
chemiczny $\mathrm{H}_{2} \mathrm{O}$, a w drugim XYZ - jak to określił Putnam ${ }^{32}$. Należy dodać, że w obu światach substancje te nazywa się „woda”. Putnam skonstruował ten eksperyment, aby znaleźć odpowiedź na pytanie o znaczenie, i jako rozwiązanie tak postawionego problemu przyjął dwie opcje. Po pierwsze można przyjąć, że wyraz „woda” w obu światach znaczy to samo, przy czym w jednym używany jest na oznaczenie $\mathrm{H}_{2} \mathrm{O}$, a w drugim na XYZ, co amerykański filozof nazywa „stałym względnym znaczeniem" ${ }^{33}$. Po drugie można przyjąć, że wyraz ,woda" oznacza $\mathrm{H}_{2} \mathrm{O}$ w każdym świecie, więc określenie XYZ mianem „wody” byłoby błędne. Nie wchodząc w dalsze wywody formalne, które konstruuje Putnam, idąc w pewnej mierze za Saulem Kripkem, należy wskazać, że istotna dla dalszych rozważań jest teza, którą jako konkluzję pierwszej odsłony swego eksperymentu przedstawia amerykański filozof. Wskazuje on, że:

twór $x$, w dowolnym możliwym świecie, jest wodą wtedy i tylko wtedy, gdy znajduje się $\mathrm{w}$ relacji jednakowości $\mathrm{L}_{\mathrm{L}}$ [indeks dolny jest w naszym kontekście nieistotny] (rozumianej jako relacja międzyświatowa) do tworu, który my nazywamy „wodą” $\mathrm{w}$ świecie rzeczywistym ${ }^{34}$.

Ta konkluzja dotyczy rzecz jasna zagadnienia, które postawił przed sobą Putnam. Dokonane ekstrapolowanie założeń wstępnych eksperymentu tak, aby mogły zostać odniesione do świata przedstawionego w dziele literackim, domaga się również ekstrapolacji konkluzji. Tu owa ekstrapolacja ma charakter podwójny: 1. do przedmiotu, 2. o dalsze relacje odpowiedniości (ew. jednakowości).

1. Mówiąc o dowolnym możliwym świecie, oczywiście będę mówił o świecie przedstawionym, czyli o zbiorze stanów rzeczy, które zostały intencjonalnie sprojektowane. Jeśli więc miałoby zachodzić formalno-materialne (ew. formalno-treściowe) utożsamienie, skorelowane dodatkowo wskaźnikiem kierunkowym nazwy, to między oboma

\footnotetext{
32 Zob. H. Putnam, Znaczenie wyrazu „znaczenie”, s. 117.

33 H. Putnam, Znaczenie wyrazu „znaczenie”, s. 118.

${ }^{34}$ H. Putnam, Znaczenie wyrazu „znaczenie”, s. 120.
} 
elementami (ew. stanami rzeczy) dwóch światów musiałaby zachodzić relacja jednakowości ${ }^{35}$.

2. Ingarden wielokrotnie podkreślał, że badanie przedmiotu naszego poznania w izolacji jest czynnością nieraz pożyteczną, ale ostatecznie sztuczną. Każdy element któregokolwiek świata jest zawsze dany w pewnych relacjach z innymi elementami. Można powiedzieć - również za polskim fenomenologiem - że elementy te wzajemnie się warunkują, a niejednokrotnie również konstytuują. Mając to na uwadze, poszerzam konkluzję Putnama w następujący sposób: jeśli jakikolwiek element danego świata jest różny od jakiegokolwiek elementu innego świata, to żaden element w obu tych światach nie może być ujmowany jako w pełni takożsamy, tożsamy czy identyczny. Jest to teza mocna i postaram się odpowiednio ją uzasadnić.

Jeżeli na tożsamość ${ }^{36}$ danego bytu wpływa również - nieważne w jakim stopniu - kontekst jego bytowania, to jedynie byty będące $\mathrm{w}$ dokładnie takich samych relacjach wewnętrznych i zewnętrznych (kontekstach) mogą być uznane za w pełni takożsame, tożsame lub identyczne. Jeśli bowiem dany $\mathrm{X}$ jest współkonstytuowany przez jakiś stan rzeczy A, to ów stan rzeczy A również jest konstytuowany nie tylko przez występowanie $\mathrm{w}$ jego obrębie $\mathrm{X}$, ale przez relacje, które łączą $\mathrm{A} \mathrm{z}$ innymi stanami rzeczy czy innymi elementami danego świata ${ }^{37}$. Wynika $z$ tego, że jest w zasadzie niemożliwe istnienie dwóch dokładnie takich samych, tożsamych lub identycznych bytów lub stanów rzeczy z tej przyczyny, że ostatecznie ich wzajemna relacja czyniłaby je różnymi. Jeśli bowiem oznaczyć oba byty (ew. stany rzeczy), o których należy orzec pełną takożsamość, tożsamość czy identyczność, jako X i Y, to możliwe jest

35 W przyjmowanej przez nas nomenklaturze: pełnej takożsamości/identyczności.

36 Tu: bycie tego bytu tym, czym jest.

37 Prezentowanego tu poglądu nie należy łączyć z tzw. efektem motyla, gdyż nie twierdzę tu niczego na temat determinizmu i uwarunkowań przyczynowo-skutkowych. Należy jednak wskazać, że w ten argument wpisuje się również następstwo czasowe - o ile mowa o bytach partycypujących w czasie. Tu zaś ujawnia się kontekstowe nawiązanie do rozwiązań uzyskanych na gruncie metafizyki przez Józefa Bańkę. Zob. J. Bańka, Sermonizm jako stanowisko recentywizmu w sporze o powszechniki, „Folia Philosophica” 26 (2008), s. 199-205, 214. 
rozpatrzenie dwóch wariantów: 1. dla bytów występujących w obrębie jednego świata; 2. dla bytów występujących w obrębie dwóch światów.

1. Jeśli w obrębie jednego świata mamy X oraz Y, a także jeżeli - co jest sprawą jasną - X oraz Y występują w pewnych stanach rzeczy (ew. same są stanami rzeczy), a te stany rzeczy ostatecznie w jakimś stopniu wzajemnie się warunkują, to nie można fortunnie twierdzić o pełnej takożsamości, tożsamości lub identyczności X oraz Y, gdyż ostatecznie obojętnie w jakim stopniu - X jest Iksem dlatego, że Y jest Igrekiem.

2. W sytuacji, gdy X i Y są ulokowane w dwóch światach (każdy w jednym), argumentacja może przyjąć dwie wersje, w zależności od relacji łączącej oba światy. W pierwszym przypadku można rozważyć dwa odseparowane w jakimś stopniu od siebie światy, gdzie owo odseparowanie jest rozumiane tak, iż jeden świat nie jest obiektywnie elementem drugiego, tj. nie zawiera się w nim. W takim wypadku rzecz jasna należy przejść na swego rodzaju „metapoziom” i jeżeli oba światy występują faktycznie, to występują w relacji "jeden wobec drugiego", co w zasadzie jest przeniesieniem argumentu z punktu 1. o poziom wyżej, tj. świat, w którym występuje X, jest dokładnie tym światem dlatego, że istnieje świat, w którym występuje Y. Ostatecznie więc znów X jest Iksem o tyle, o ile Y jest Igrekiem.

W drugim wariancie jeden świat obiektywnie przynależy do drugiego świata. To właśnie jest sytuacja dzieła literackiego i świata przedstawionego. Mimo iż Ingarden twierdzi, że świat przedstawiony jest jakoś odrębnym światem, to oczywiście nie podważa tym samym twierdzenia, iż obiektywnie - o ile oba światy istnieją - świat przedstawiony w dziele literackim jest częścią świata rzeczywistego ${ }^{38}$. Mimo różnych sposobów istnienia obu światów jeden stanowi warunek konieczny dla powstania $\mathrm{i}$ trwania drugiego. W tej sytuacji argumentację należałoby powtórzyć, tj. ten świat rzeczywisty jest dokładnie tym światem rzeczywistym dlatego, że występują w nim takie, a nie inne dzieła literackie prezentujące takie, a nie inne światy przedstawione. Zatem, jeżeli w świecie przedstawionym

${ }^{38} \mathrm{~W}$ takim rozumieniu, że jako byt intencjonalnie sprojektowany jest po prostu jednym $\mathrm{z}$ elementów świata rzeczywistego. 
jest jakieś $\mathrm{Y}$, a w świecie rzeczywistym jakieś $\mathrm{X}$, co do których należy określić ewentualną pełną takożsamość, tożsamość lub identyczność, to po raz kolejny $\mathrm{X}$ jest Iksem (znów: nieważne jaki jest stopnień wpływu czy zależności), o ile Y jest Igrekiem.

Jak kwestię tę przełożyć na utożsamianie miejsc rozgrywania się akcji, od których rozpocząłem tę dyskusję? Otóż, jeśli mamy np. plac Dominikański w Krakowie, to jest to właśnie to miejsce $\mathrm{z}$ taką, a nie inną historią, którego tożsamość jest ukonstytuowana w realnym świe$\mathrm{cie}^{39}$. Ów realny świat, który jest $\mathrm{w}$ pełni dookreślony, nie pozostawia miejsca na jakiekolwiek przeszłe zmiany czy niedookreślenia. Jeśli więc w pewnej powieści autor przedstawiłby następującą sytuację: „Na krakowski plac Dominikański wraz z adiutantami wjechał w mroźny styczniowy poranek Napoleon", to, o ile takie zdarzenie nie zaszło faktycznie w rzeczywistości, nie można dorzecznie twierdzić, że ów krakowski plac Dominikański ze świata rzeczywistego i ze świata przedstawionego są tym samym miejscem. Jeśli dwa miejsca mają różną historię choćby w jednym „punkcie”, to pełna takożsamość, tożsamość czy identyczność zachodzić nie może. Jedyne, co może zachodzić, to pewne wzorowanie, odtwórczość itd., o których Ingarden pisał dość szeroko ${ }^{40}$. Z faktu, że przez wyrażenie nazwowe czytelnik (ew. odbiorca) odnosi się $^{41}$ do znanego mu z rzeczywistości miejsca, nie wynika jeszcze, że miejsce ze świata przedstawionego i miejsce ze świata rzeczywistego to te same miejsca.

Należy tu również wskazać, że gdyby chcieć rozwijać tę argumentację w kierunku możliwości istnienia dwóch dokładnie takich samych bytów w dwóch różnych światach, to ostatecznie okazałoby się, że są to byty tożsame w tym sensie, że jest to jeden i ten sam byt.

39 Kwestii, czy miejsce faktycznie może mieć tożsamość, tu nie rozwijam i przyjmuję, że może, chociaż nie uznaję tego za rozwiązanie niewątpliwe.

40 Zob. R. Ingarden, O dziele literackim, $\$ 37$.

41 Ingarden raczej powiedziałby, że to „wyrażenie nazwowe odnosi”, ale przyjmując za zasadną argumentację Putnama w kwestii tzw. magicznej teorii referencji, używam nieco innego szyku zdania. Zob. H. Putnam, Mózgi w naczyniu, w: H. Putnam, „Wiele twarzy realizmu” i inne eseje, s. $298-302$. 
Proponowane tu rozwiązanie nie jest wole od swoistych trudności:

1. Recentywizm jako metafizyczna podstawa argumentu ${ }^{42}$ może budzić wątpliwości nie tyle $\mathrm{z}$ faktu jego zastosowania, ile ze względu na samo stanowisko metafizyczne. Nie miejsce jednak po temu, aby rozważać tu zasadność propozycji Józefa Bańki.

2. Ekstrapolacja Putnamowskiego eksperymentu myślowego opiera się w pewnej mierze na analogii, co może, ale nie musi stanowić o słabszych miejscach przyjmowanej argumentacji.

3. Nieporuszone zostały kwestie epistemologiczne, których rozważenie być może pozwoliłoby odpowiedzieć na pytanie o to, dlaczego wskaźnik kierunkowy nazwy miałby być czymś tak dalece „zwodniczym”, że aż w nastawieniu nie dość krytycznym czytelnik (ew. odbiorca) utożsamiałby miejsce ze świata rzeczywistego z miejscem ze świata przedstawionego.

Zdaję sobie sprawę z tych trudności i nie roszczę pretensji do monopolu na rozwiązanie podniesionej przez Ingardena kwestii. Chciałem jedynie zaprezentować pewne alternatywne rozwiązanie problemu, z którym - być może - miejscami filozof ten mógłby się zgodzić, a które skutkuje - jak mniemam - mniejszą liczbą problemów wynikających $\mathrm{z}$ interpretacji i rozumienia dzieła literackiego niż stanowisko polskiego fenomenologa, co nie znaczy, że problemy wstępne, np. metafizyczne, są mniej ciążące niż w stanowisku Ingardenowskim.

\section{Podsumowanie}

Chciałbym teraz wskazać, dlaczego proponowane rozwiązanie mogłoby w pewnym stopniu wpisywać się w teorię literatury Ingardena. Mimo iż krakowski myśliciel zakładał istnienie idei i jakości idealnych, z których konkretyzacjami obcujemy w omawianych światach, to jednak indywidua $\mathrm{z}$ obu omawianych światów traktował on w sposób podobny

42 Abstrahuję tu od antropologicznych czy epistemologicznych implikacji recentywizmu. 
do tego, który leży u podstaw mojej argumentacji ${ }^{43}$. Na dany przedmiot (ew. stan rzeczy), a więc i na konkretne miejsce, aby było tym dokładnie miejscem, składa się całość zdarzeń mniej lub bardziej (pośrednio lub bezpośrednio) wpływających na to, co konstytuuje tożsamość tego przedmiotu, stanu rzeczy czy miejsca ${ }^{44}$. Wobec tego można powiedzieć, że przedstawiona argumentacja przynajmniej częściowo wpisuje się w ontologię literatury Ingardena. Nie stawiam tu pytania o konsekwencje jej przyjęcia i zestawienie tychże $\mathrm{z}$ konsekwencjami propozycji tego filozofa, gdyż nie jest to przedmiotem artykułu.

Podsumowując, Ingarden widział możliwość osadzania przedmiotów intencjonalnych będących elementami świata przedstawionego w miejscach rzeczywistych, które stanowiłyby niejako również elementy świata przedstawionego. Wyznaczały to według niego: wskaźnik kierunkowy nazwy i kwestie formalno-materialne (ew. formalno-treściowe). Korzystając $\mathrm{z}$ argumentacji opartej na poszerzonym eksperymencie myślowym Putnama i odwołując się kontekstowo do recentywizmu Bańki, przedstawiłem argumentację, z której wynika, że niemożliwe jest twierdzenie przyjmowane przez Ingardena, jakoby miejsce ze świata rzeczywistego było miejscem rozgrywania się akcji dokonującej się w świecie przedstawionym. Dla filozofii literatury opracowanej przez autora Sporu o istnienie świata może mieć to znaczenie o tyle istotne, że umożliwia ściślejsze odseparowanie dwóch dziedzin bytowych, których miejsca rzekomo wspólne - jak chociażby omawiane miejsca rozgrywania się akcji generowały nierozwiązane przez Ingardena problemy. Nawet założywszy, że dałoby się fortunnie w obrębie jego filozofii te problemy rozwikłać, to pozostaje pytanie, czy nie byłoby to zbędne rozbudowywanie systemu ze względu na niedostrzeżenie możliwości, a w zasadzie konieczności, separacji miejsca rozgrywania się akcji przedstawionej w dziele literackim i miejsca ze świata rzeczywistego. Proponowane rozwiązanie daje

43 To podobieństwo jest widoczne zwłaszcza przy wzięciu pod uwagę kwestii zdarzenia i procesu. Zob. R. Ingarden, Spór o istnienie świata, t. 2/1, Warszawa 1987, $\$ 61$.

${ }^{44}$ Raz jeszcze podkreślam: zakładając, że miejsce ma jakąś tożsamość. 
zatem możliwość uspójnienia w pewnym wąskim zakresie rozbudowanej i skrupulatnie przedstawionej filozofii literatury Ingardena.

Wskazana argumentacja jest jedynie próbą ujęcia podniesionego przez Ingardena problemu od nieco innej strony - być może nawet takiej, w którą ów filozof szedł, i jedynie uwypukla jego intuicje. Wymaga ona z pewnością dodatkowych analiz i poszerzonych badań na różnych płaszczyznach, ale jej skonstruowanie i przedstawienie stanowi dogodny przyczynek do dalszych badań.

\section{Bibliografia}

Bańka J., Sermonizm jako stanowisko recentywizmu w sporze o powszechniki, „Folia Philosophica" 26 (2008), s. 199-220.

Głowiński M., O konkretyzacji, w: M. Głowiński, Style odbioru: szkice o komunikacji literackiej, Kraków 1977, s. 91-109.

Ingarden R., O dziele literackim. Badania z pogranicza ontologii, teorii języka i filozofii literatury, Warszawa 1960.

Ingarden R., O poznawaniu dzieła literackiego, Warszawa 1976.

Ingarden R., O pytaniach esencjalnych, w: R. Ingarden, $Z$ teorii języka i filozoficznych podstaw logiki, Warszawa 1972.

Ingarden R., Spór o istnienie świata, t. 2/1, Warszawa 1987.

Pelc J., Quasi-sqdy a dzieło literackie, „Pamiętnik Literacki” 54 (1963) 3, s. 61-79.

Petryszak K., Ontologia kultury. Badania nad kultura w oparciu o zmodyfikowana ontologię Romana Ingardena, Kraków 2021, doi: 10.15633/9788374387767.

Popper K., Wszechświat otwarty. Argumenty na rzecz indeterminizmu, Kraków 1996.

Putnam H., Mózgi w naczyniu, w: H. Putnam, „Wiele twarzy realizmu” $i$ inne eseje, Warszawa 1998, s. 295-324.

Putnam H., Znaczenie wyrazu „znaczenie”, w: H. Putnam, „Wiele twarzy realizmu” i inne eseje, Warszawa 1998, s. 93-184.

Rosiak M., Spór o substancjalizm. Studia z ontologii Ingardena i metafizyki Whiteheada, Łódź 2003.

Rosiak M., Zagadnienie postaktualności. Z ontologii egzystencjalnej tego, co przeminęło, „Lectiones \& Acroases Philosophicae” 5 (2012) 2, s. 33-46. 
Słownik terminów literackich, pod red. M. Głowińskiego, T. Kostkiewiczowej, A. Okopień-Sławińskiej, J. Sławińskiego, Wrocław 2008.

Stępień A.B., Uwagi o Ingardenowskiej koncepcji ontologii, w: Spór o Ingardena, pod red.

J. Dębowskiego, Lublin 1994, s. 17-26.

Stróżewski W., Wokót piękna, Kraków 2002.

Szczepańska A., Estetyka Romana Ingardena, Warszawa 1989.

Świderski E., Pewne główne rysy ontologii Ingardena, „Studia Philosophiae Christianae” 14 (1978) nr 1, s. 89-108.

Ulicka D., Ingardenowska filozofia literatury. Konteksty, Warszawa 1992.

Ziomek J., Fikcyjne pole odniesienia a problem quasi-sądów, w: Wypowiedź literacka a wypowiedź filozoficzna, pod red. M. Głowińskiego i J. Sławskiego, Wrocław-WarszawaKraków-Gdańsk-Łódź 1992, s. 199-209.

\section{Abstrakt \\ Miejsce czy miejsca? Kilka uwag na temat propozycji Romana Ingardena dotyczących łączenia intencjonalnych i rzeczywistych miejsc w dziele literackim}

W artykule została przedstawiona propozycja uzupełnienia filozofii literatury Romana Ingardena. Fenomenolog ten zakładał, że między miejscem rozgrywania się akcji w dziele literackim a faktycznym miejscem - jeśli na takie miejsce wskazywałoby dzieło literackie (np. ul. Grodzka w Krakowie) - zachodzi pewna tożsamość lub pewna łączność. W oparciu o poszerzoną na potrzeby tematu argumentację Hilarego Putnama i metafizyczne aspekty recentywizmu Józefa Bańki przedstawiono argumenty wskazujące, że nie jest możliwe utrzymanie twierdzenia o łączności między miejscami intencjonalnymi w dziele literackim a miejscami rzeczywistymi. Przedstawiono również konsekwencje takiego uzupełnienia wskazanego punktu filozofii literatury Ingardena.

\section{Słowa kluczowe}

Roman Ingarden, filozofia literatury, miejsce, dzieło literackie, Hilary Putnam, Józef Bańka, ziemia bliźniacza, recentywizm 


\section{Abstract \\ Place or Places? Some Thoughts on Roman Ingarden's Proposals for Linking Intentional and Actual Places in a Literary Work}

The following paper presents a proposal to complement Roman Ingarden's philosophy of literature. Ingarden assumed that there is some identity or some connection between the place where the action takes place in a literary work and the real place, if such a place is indicated by a literary work (e.g. Grodzka Street in Krakow). Based on the arguments of Hilary Putnam, extended for the purposes of the topic, and metaphysical aspects of recentivism by Józef Bańka, arguments are presented to show that it is not possible to maintain a claim of connectivity between intentional places in a literary work and actual places. The consequences of such an addition to the indicated point of Ingarden's philosophy of literature are also pointed out.

\section{Keywords}

Roman Ingarden, philosophy of literature, place, literary work, Hilary Putnam, Józef Bańka, twin earth, recentivism 